\title{
A Raster-based model for flood inundation mapping on delta lowland
}

\author{
Nurhamidah Nurhamidah ${ }^{1, *}$, Bujang Rusman ${ }^{2}$, and Bambang Istijono ${ }^{1}$ \\ ${ }^{1}$ Civil Engineering Department, University of Andalas, Padang, Indonesia \\ ${ }^{2}$ Soil Science Department, University of Andalas, Padang, Indonesia
}

\begin{abstract}
A high intensity of rainfall experiences flooding in some areas. Flooding can be caused by several aspects, such as inadequate urban drainage, reduce the porous surface due to rapid development and the topography of the area itself. Flood has always been a scourge for the inhabitants of Padang city. Especially when there are a heavy-rain and long duration, certainly flood will hit some places in Padang city. Therefore, many things that must be considered by the local government in overcoming the problem of this flood, including improvements of the drainage system, reforestation and create the polders. In this research, it is described the area of the prone area in Padang city with spatial analysis tools which are approached in the Geographical Information System. Based on the topography of the Padang city, inundated areas and flood direction will be presented in case of the heavy rain occurs. From the analysis, there are several points of vulnerable inundation in Padang city that are generally located in densely populated areas and main roads in Padang city which can be considered for the future planning.
\end{abstract}

\section{Introduction}

A high intensity of rainfall experiences flooding in some areas. Flooding can be caused by several aspects, such as inadequate urban drainage, reduce the porous surface due to rapid development and the topography of the area itself. Flood has always been a scourge for the inhabitants of Padang city. Especially when there are a heavy-rain and long duration, certainly flood will hit some places in Padang city. Therefore, many things that must be considered by the local government in overcoming the problem of this flood, including improvements of the drainage system, reforestation and create the polders. In this research, it is described the area of the prone area in Padang city with spatial analysis tools which are approached in the Geographical Information System. Based on the topography of the Padang city, inundated areas and flood direction will be presented in case of the heavy rain occurs. From the analysis, there are several points of vulnerable inundation in Padang city that are generally located in densely populated areas and main roads in Padang city which can be considered for the future planning.

The methodology is approached with D8 matrix model in order to determine where the flow is directed and accumulated [1]. The boundary areas are assessed according to the district in Padang city, West Sumatera Province, Indonesia.

\section{GIS raster based hydrological modeling}

In general, Geographic Information System (GIS) is a component consisting of hardware, software, geographic data and human resources that work together effectively to incorporate, store, repair, update, manage, manipulate, integrate, analyse and display data in a geographic-based information. GIS is a database that usually has spatial components in processing, store and produces the maps. It also offers the potential to run multiple analyses or evaluate a scenario similar to model simulation [2]. The data collected from various sources and it may overlap information from various data sources through various themes and layers [3].

Most data sources come from remote sensing data of both satellite and aerial photography; therefore, GIS technology is related to remote sensing, although remote sensing is not the only science supporting this system. However, the other supporting data from field survey and measurement are still needed and other secondary data such as census results, records, and reports from trusted sources are required. Spatial data from remote sensing and surveys are stored in databases utilizing digital computer technology for processing and decision making [4].

In GIS technology, there are many advantages, one of them for research of water resources. GIS allows for better structuring and data storage. The objectives of many watershed studies include the division of watersheds, identification of drainage and river channel networks, slope and face characterization, water 
catchments configurations and flow behaviour. Generating these variables is difficult to do from print maps and aerial photographs. The traditional method became the subject of mistakes due to manual operation and proved to take a long time [2]. This technology can be used for scientific investigation, resource management, cartography, and route planning. Besides, this GIS can help in planning to calculate the response quickly $[5,1]$.

\subsection{Data spatial}

A spatial reference is a pointer for such a location, whether in a direct form indicated as a coordinate, an address or a position relative to another location [6]. Spatial corresponds to a coordinate of both geographic coordinates (latitude and longitude) and XYZ coordinates, including datum and projection information. Spatial data of GIS format can be represented in two formats; vector and raster data. The vector data is the shape of the earth that is represented into a set of lines, the area (the area bounded by a line that begins and ends at the same point), dots and nodes (the intersection point between two lines). Raster data also called the grid cell is the data generated from the remote sensing system. In raster data, geographical objects are represented as grid cell structures called pixels (picture elements).

Data of Remote Sensing System among others satellite imagery; aerial photography is the most important source of data for GIS because its availability is scale and covers a certain area. Survey data obtained based on the results of the field measurement. This kind of data is a source of attribute data. For instance, administrative, area, land cover, land use boundaries.

Global Positioning System (GPS), technology provides data for GIS. The accuracy of GPS measurement is increasing with the development of technology. The process in the GIS is divided into data input, data processing, manipulation and analysis of data, output data and overlay.

Data input system is a facility within GIS used to enter data and change the form of data that can be accepted and used in GIS. Data entry is done in 3 ways; scanning, digitize and tabulation. Scanning, the process of converting continuous graphics data to graphical data composed of pixel cells. Concerning the scanning, the data is stored in raster shape. Digitize the process of converting the graphical data into digital graphical data in vector configuration. In this vector, the data is stored in terms of points, lines or polygon. Tabulation, the database in the GIS is grouped into the graphics and attribute database. Data processing includes all storage operations, activation, re-storage, and printing of all data obtained from data input. data management, fixes, reductions, and additional information.

The function of this subsystem is to distinguish data to be processed in GIS. To change the data format, get the parameters and processes in the data management. Evaluation of these subsystems, need to be continued in order to generate the subsystem.
This subsystem serves to show the information and analysis of both geographical data quantitatively and qualitatively. The output can be a map, table or archive, which can be print out in hard copy.

This overlay can actually be done manually; however, it will be limited. If the map assembles more than 4 layers, there will be a big complexity and it is difficult to claim again in presenting new mapping. The overlay is the core of GIS operations that define GIS. If the software can overlay, it is certain that the application is a GIS application and not just as a cartographic application (Albrecht, 2007). Overlay process requires precision in the same location. In other words, a data contained in a feature class and other feature data combination.

\subsection{Digital elevation model}

Digital Elevation Model (DEM) is a model to describe the topography of the earth surface, it can be visualized into three dimensional. There are many ways to obtain DEM data, SAR interferometry (Synthetic Aperture Radar) is one of the algorithms for creating relatively new DEM data. SAR image data or radar images are used in the interferometry process and obtained from satellite. SRTM (Shuttle Radar Topography Mission) is a mission to create topographic data (DEM) using a radar system. DEM data from this mission is available worldwide for $30 \mathrm{~m}$ and $90 \mathrm{~m}$ spatial resolution.

Nurhamidah (2016) determined the flood-prone zone in the delta area of the Siak river by using the D8 spatial analysis tools system at GIS. In the D8 model, the direction of flow in the study area, so there can be seen where the flow direction and the intersection which indicates the flood-prone areas. The study area was also studied about the high inundation that occurred by comparing the volume of rainfall within the study area.

Sulfiani (2015) indicates areas of flood inundation in Makassar using Topography Wetness Index. She examined flood prone with surface conditions of an area, slope, land use, soil texture, etc. She also extracted the high inundation by rational methods, the obtained discharges are divided by the area in order to obtain the flood water depth.

In general, flooding is caused by high rainfall. During the heavy rain, the drainage systems become stagnant and inadequate. This situation creates the flow accumulation and inundation in some areas. The river and drainage capacity are changing all the time due to the sedimentation. Deforestation in the catchment area influences an increasing of flood discharge, the flow system becomes exceed the drainage capacity and becomes the trigger for erosion on steep terrain. The erosion will produce sedimentation on the downstream channels. In residential areas that have been densely occupied with buildings, the infiltration rate into the soil is reduced, on the other hand, the heavy rain will increase the water surface runoff which creates the inundation. 


\subsection{GIS raster based hydrological modelling}

\subsubsection{Raster-based model}

Application of remote sensing in hydrology is intended to detect, identify and map the land surface. Hydrological interpretation of remote sensing techniques performed to estimate the appearance of landscape features interaction with hydrologic processes.

Distribution of runoff derived from rainfall data can be performed with the data processing and analysis using DEM (Digital Elevation Model). Data DEM derived from SRTM radar image, extraction of DEM is used as a slope map-making, as well as to assist in the interpretation of landforms. In addition, data were also analysed DEM hydro-modelling such as network flow and the determination of land cover map derived from Landsat TM imagery. Visual interpretation of the colors used in the manufacture of composite landform map of the study area.

Processing of DEM which is derived data from SRTM radar image produced a hydrological assessment of flow determination, such as watershed delineation, flow direction, sink, flow accumulation, stream order, and stream link, and streamline, flow length, snap pour.

\subsection{2. $D 8$ flow model}

D8 model is a determination model of a stream direction based digital elevation model (DEM). It is very important in hydrology modelling in order to find out which way a landscape flows [7-10]. There are eight valid output directions relating to the eight adjacent cells into which flow could travel. This approach is commonly referred to as an eight-direction (D8) flow model and follows an approach presented in $[11,12]$.

The direction of flow is determined by finding the direction of steepest descent, or maximum drop, from each cell. D8 model is connected with GIS under spatial analysis tool. Using the elevation data, which is generated from DEM, it assumes that the water particles in every cell from DEM flow into the one of the nearest grid. For every grid cell on the surface, the grid processor will detect the steepest directions [12-16]. The stream direction is a function of a point, on each matrix $3 \times 3$. On each matrix $3 \times 3$ of the nearest grid cell, grid processor will stop on a central point that is in the middle and will find out the lowest region in the grid matrix $3 \times 3$. However, it depends on the direction of a stream; each grid output will have its own value as shown in the Fig. 1.

\section{Research methodology}

\subsection{Description of study area}

The study areas are located in Padang, West Sumatera, Indonesia, covering an area of $694.96 \mathrm{~km}^{2}$. Padang has a high rainfall, this results in flooding every year. Padang has a population of about 856,815 people, spread across 11 districts namely; Bungus, Koto Tangah, Kuranji,
Lubuk Begalung, Nanggalo, Pauh, Padang Utara, Padang Barat, Padang Selatan and Padang Timur (Fig. 2).

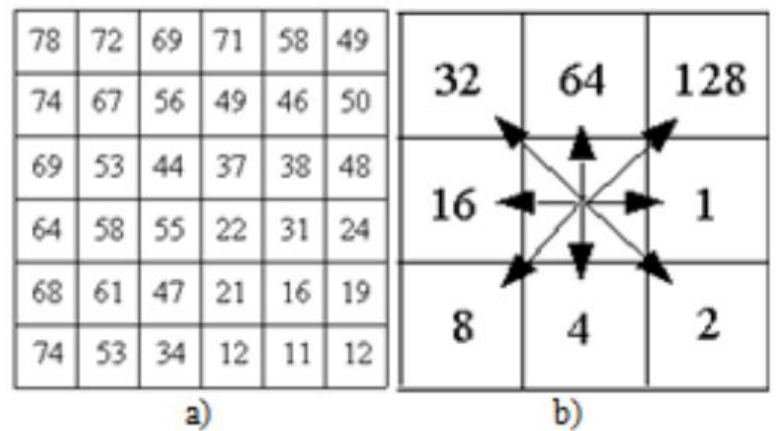

\begin{tabular}{|c|c|c|c|c|c|c|c|c|c|c|c|}
\hline 2 & 2 & 2 & 4 & 4 & 8 & $\downarrow$ & $\downarrow$ & 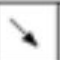 & $\downarrow$ & $\downarrow$ & $\checkmark$ \\
\hline 2 & 2 & 2 & 4 & 4 & 8 & $\downarrow$ & 4 & 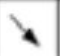 & $\downarrow$ & $\downarrow$ & $\checkmark$ \\
\hline 1 & 1 & 2 & 4 & 8 & 4 & $\rightarrow$ & $\rightarrow$ & 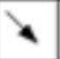 & $\downarrow$ & $\checkmark$ & $\downarrow$ \\
\hline 128 & 128 & 1 & 2 & 4 & 8 & $x$ & 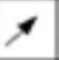 & $\rightarrow$ & $\lambda$ & $\downarrow$ & $\checkmark$ \\
\hline 2 & 2 & 1 & 4 & 4 & 4 & 4 & $\downarrow$ & $\rightarrow$ & $\downarrow$ & $\downarrow$ & $\downarrow$ \\
\hline 1 & 1 & 1 & 1 & 4 & 16 & $\rightarrow$ & $\rightarrow$ & $\rightarrow$ & $\rightarrow$ & $\downarrow$ & $\leftarrow$ \\
\hline
\end{tabular}

Fig. 1. The analysis of flow direction and accumulation using D8 model, a) Elevation b) Flow direction code c) The value of grid d) Arrow symbols of flow direction.
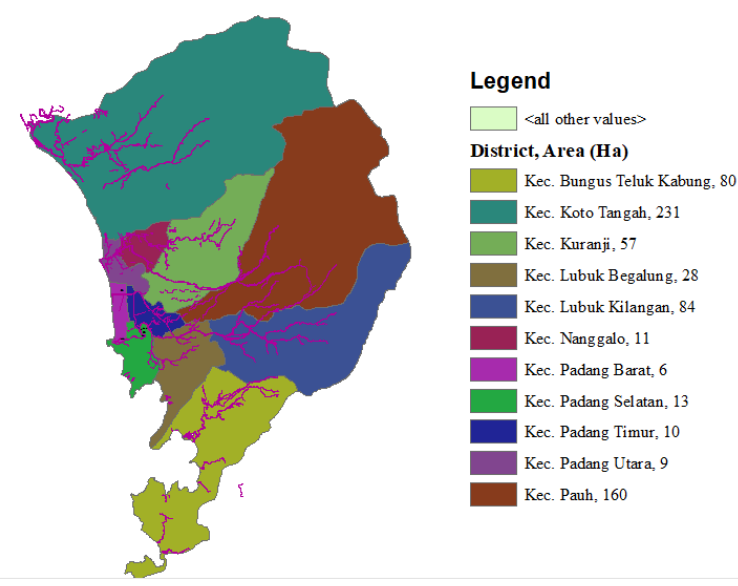

Fig. 2. Padang city and its districts

Some of these sub-districts become flood subscriptions whenever there is heavy rain. Padang is surrounded by a row of hills so that when heavy rains occur, runoff from the hills will move quickly towards Padang with a very large amount of discharge. If the soil is water saturated, and the drainage is full, then there will be widespread inundation in some districts. The shape of the Padang topography can be illustrated as follows:

There are 8 large rivers with a large catchment area, runoff that occurs when the rain will flow into the river through drainage and surface flow. So it is necessary drainage channels with a large capacity, so as not to 
cause puddles in some areas. Map of drainage and river networks in Padang can be described as follows:

1. The catchment boundaries within the Padang city area are influenced by topographic forms and river flows. In general, the catchment is limited by ridges or mountains, collecting rainwater that falls in the area, streaming it through tributaries and river mains to the sea or to the lake.

2. The aspects of land use planning in the city of Padang include forests, rice fields, plantations, settlements, and urban areas. On the map, it can be described that Padang consists mainly of densely populated of settlements and forests. The settlement areas of Padang Padang will be inundated with high flood level because the surface runoff coefficient in the residential area gets closer to value 1 .

\subsection{Deriving runoff characteristics}

When delineating watersheds or defining stream networks, you proceed through a series of steps. Some steps are mandatory, while others are optional depending on the characteristics of the input data. Flow across a surface will always be in the steepest downslope direction. Once the direction of flow out of each cell is known, it is possible to determine which and how many cells flow into any given cell. This information can be used to define watershed boundaries and stream networks. The following flowchart (Fig.3) shows the process of extracting hydrology information, such as watershed boundaries and stream networks, from a digital elevation model (DEM).

The data are taken from local government and USGS satellite which can be downloaded at http://earthexplore.usgv.gov/, available on $90 \mathrm{~m}$ and $30 \mathrm{~m}$ grid. The research will create the inundation depth and areas due to rainfall accumulation on the surface land, which is approached with Geographic Information System (GIS). In this research, the DEM data uses DEM grid of 30 meters, among of Padang.

\section{Result and discussion}

The catchment area was digitized to obtain a watershed map. This data processing is in order to get an idea of which areas are affected by any river stream and any area that can become flooded. The land use map is processed to obtain a land classification data and extents for each land cover within the study location area by performing an on-screen digitization process on the satellite image.

Preparation of flood level in Nanggalo Subdistrict was analysed by using the D8 method by looking at flow direction at sub-district of Nanggalo. Using Spatial analysis of DEM data can also be derived from slope as an input parameter to determine the inundation area.

Determination of depth and flooded area obtained the distribution of surface runoff. It is well known that the discharge and the extent of the flooding are obtained from the inundation area, the next step is the design process to know the depth of the flooding.

Determination of the inundation area which is determined by the D8 method in spatial analysis tools uses the principle of the slope of the region at the location and look forward to the direction of the flow that occurs. By identifying the direction of flow, it can be determined by the intersection of the flow that can make the area vulnerable to flooding.

By using Spatial Analyst Tools and Hydrology then based on DEM data of Padang City, then the flow direction will be figured out as Fig. 4.

Furthermore, the flow direction map is analysed where the flow direction is and where it is potentially to be flood-prone areas. The determination of the depth and the extent of the inundation was obtained from the method of less than the equal method in spatial analysis tools. The following curve shows the correlation between the depth of flooding and the inundated areas according to the seven districts in Padang.

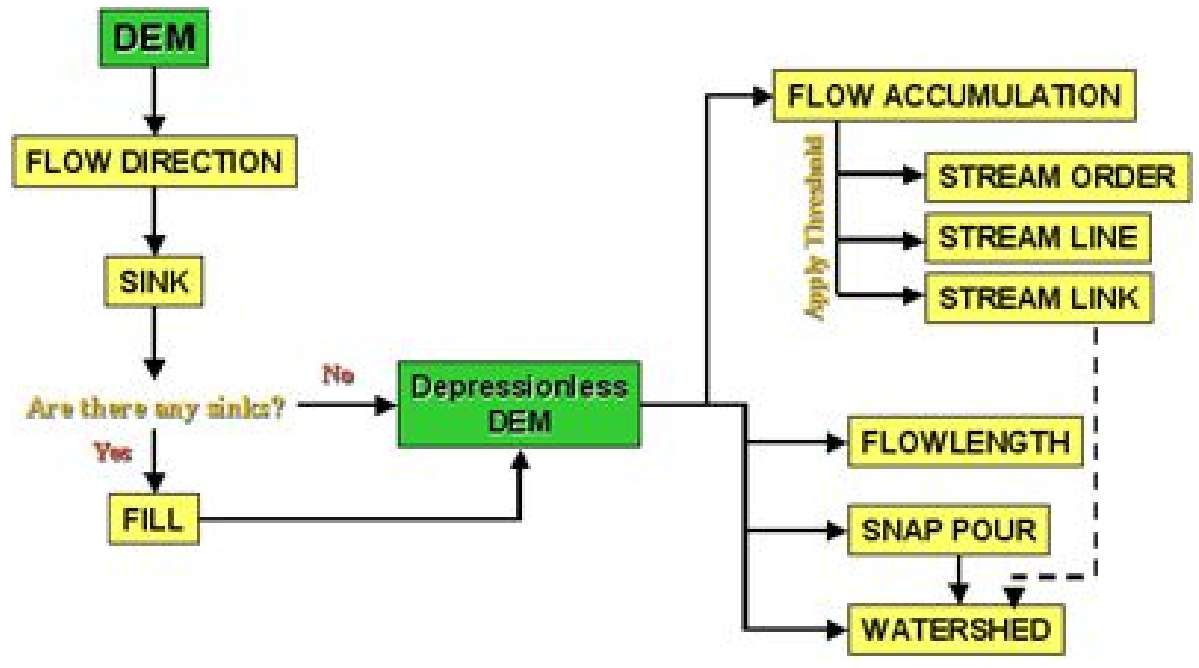

Fig. 3. The flowchart of the process of extracting hydrology information 


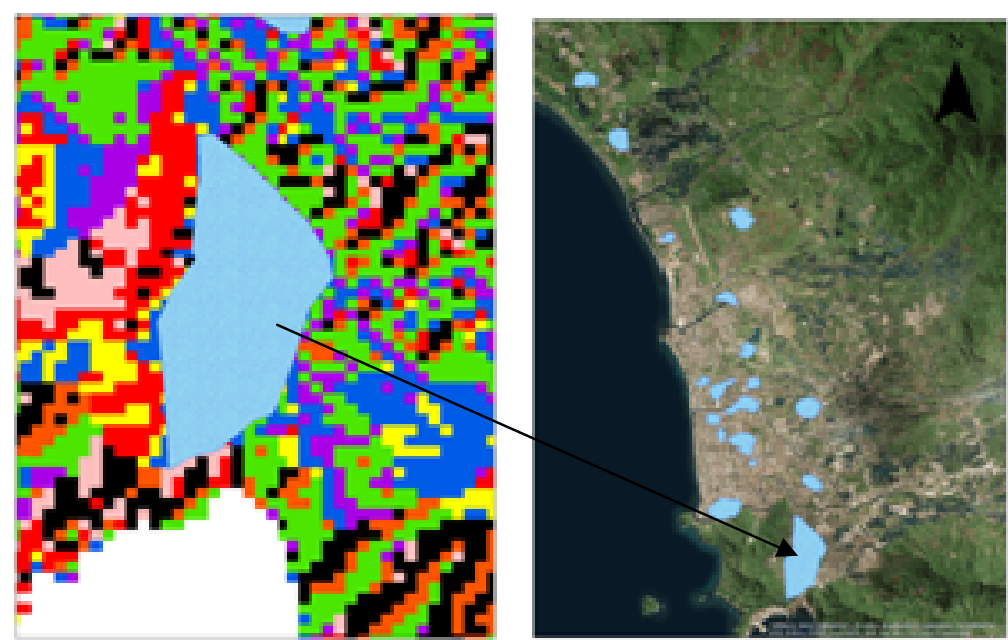

Fig. 4. Flow accumulation and inundated areas in Padang city (refer to Fig. 2)

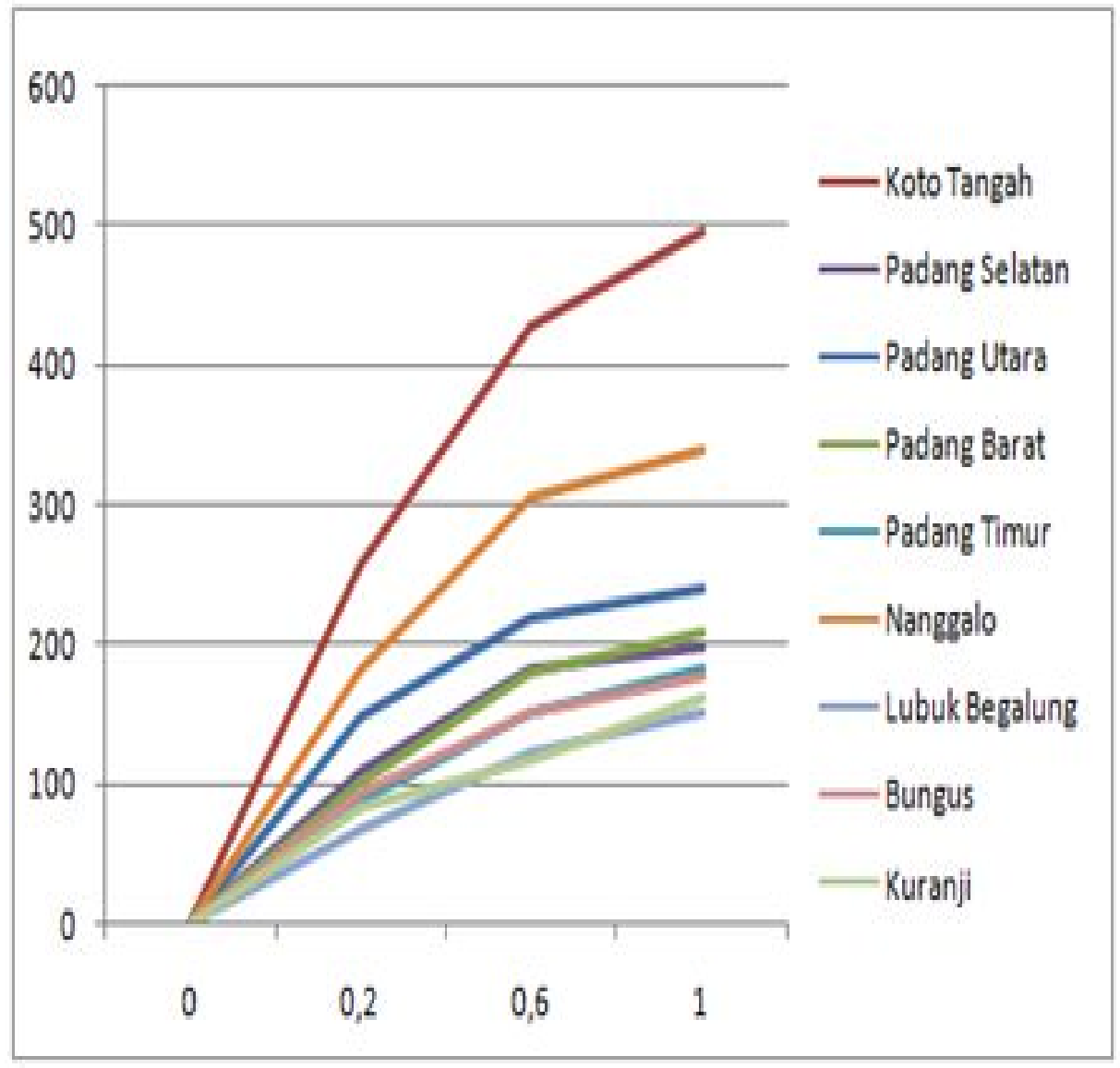

Fig. 5. The correlation between flood depth (m) and inundation areas $\left(\mathrm{km}^{2}\right)$ 


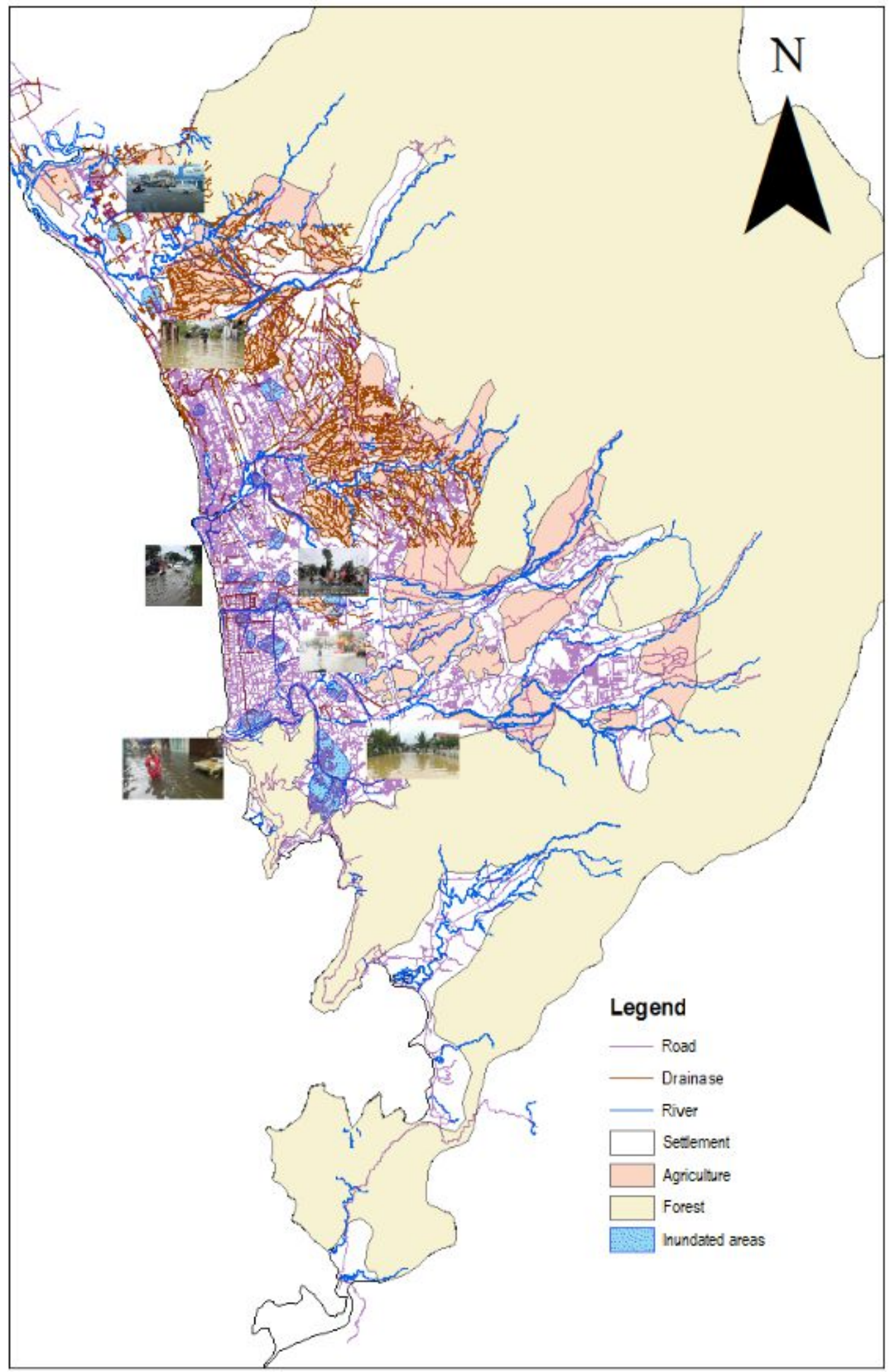

Fig. 6. The potential flooded area in Padang. 
As can be seen in the above curve, Koto Tangah and Nanggalo sub-districts have the widest flood impact compared to other sub-districts. In Koto Tangah subdistrict, if the height of the puddle occurred 1 meter then the area that was submerged almost $5.4 \mathrm{~km}^{2}$. In Fig. 6, the map shows the relationships associated with the point of vulnerable inundation in Padang city.

The point of inundation is found on the main road in Padang city center. Therefore, if there is rain with high intensity, some public service access and offices in Padang will be shutting down immediately, due to floods that inundate the region. Flooding also occurs in areas that occupied by settlement, proving that surface runoff that occurs on roads is not flow directly well into the drainage system will result in some inundation.

\section{Conclusions}

Padang has many points of potential prone to flooding. The potential flood areas are generally located in densely populated areas, public service areas and main road in the city of Padang. It needs an immediate response to anticipating the bigger risk of flooding in the city of Padang by the improvement of the urban drainage system. The more accurate prediction takes some additional parameters that affect the occurrence of flooding or surface runoff, such as the effect of tides and drainage, and river flow data. The utilization of green areas of land needs to be done to reduce the occurrence of an increase in runoff coefficient.

The first author acknowledges to the Faculty of Engineering, University of Andalas, Padang, Indonesia. This article is supported by Grant-in "Hibah Publikasi Fakultas Teknik Universitas Andalas" contract nr. 026/UN.16.09.D/PL/2018. Authors greatly appreciate the financial support.

\section{References}

1. Nurhamidah, N., A. Junaidi, and L. Anggraini, An Immediate Review of Flood Characteristics on Delta Lowland Sumatra using D8 Model Spatial Analysis. International Journal of Earth Sciences and Engineering, 2016. 09(03): p. 436-442.

2. Lyon, J.G., GIS for water resources and watershed management, in GIS for Water Resource and Watershed Management2003, CRC Press. p. 17-22.

3. Galati, S.R., Geographic information systems demystified 2006.

4. Budiyanto, E., Sistem Informasi Geografis Menggunakan ArcView GIS2002: Penerbit Andi.

5. Daoed, D., et al., Predictions of Vulnerability Flood and Flood Prone Areas in Watershed West Sumatra Province using Arc-GIS and Category Value. 2016.

6. Albrecht, J., Key concepts and techniques in GIS2007: Sage.

7. Lee, G.-H., S.-S. Lee, and K.-S. Jung, Development of a Raster-based two-dimensional flood inundation model. Journal of Korean Society of Hazard Mitigation, 2010. 10(6): p. 155-163.
8. Moore, I.D., Hydrologic modeling, and GIS. GIS and environmental modeling: Progress and research issues, 1996: p. 143-148.

9. Wilson, J.P. and M.S. Lorang, Spatial models of soil erosion and GIS. Spatial models and GIS: new potential and new models, 1999: p. 83-108.

10. Moore, I., et al., GIS and land-surface-subsurface process modeling. Environmental modeling with GIS, 1993. 20: p. 196-230.

11. JO, D., S. Jenson, and J. Dominique, Extracting topographic structure from digital elevation data for geographic information system analysis. Photogrammetric Engineering and Remote Sensing, 1988. 54: p. 1593-1600.

12. Rahman, M., D. Arya, and N. Goel, Limitation of 90 $m$ SRTM DEM in drainage network delineation using D8 method-a case study in the flat terrain of Bangladesh. Applied Geomatics, 2010. 2(2): p. 4958.

13. Fairfield, J. and P. Leymarie, Drainage networks from grid digital elevation models. Water resources research, 1991. 27(5): p. 709-717.

14. Tarboton, D.G., A new method for the determination of flow directions and upslope areas in grid digital elevation models. Water resources research, 1997. 33(2): p. 309-319.

15. Tarboton, D.G. Terrain analysis using digital elevation models in hydrology. in 23rd ESRI international users conference, San Diego, California. 2003.

16. Tarboton, D.G., Terrain analysis using digital elevation models (TauDEM). Utah State University, Logan, 2005. 